\title{
Hypatia and Her Mathematics
}

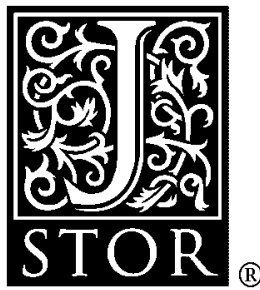

\author{
Michael A. B. Deakin
}

The American Mathematical Monthly, Vol. 101, No. 3. (Mar., 1994), pp. 234-243.

Stable URL:

http://links.jstor.org/sici?sici=0002-9890\%28199403\%29101\%3A3\%3C234\%3AHAHM\%3E2.0.CO\%3B2-D

The American Mathematical Monthly is currently published by Mathematical Association of America.

Your use of the JSTOR archive indicates your acceptance of JSTOR's Terms and Conditions of Use, available at

http://www.jstor.org/about/terms.html. JSTOR's Terms and Conditions of Use provides, in part, that unless you have obtained prior permission, you may not download an entire issue of a journal or multiple copies of articles, and you may use content in the JSTOR archive only for your personal, non-commercial use.

Please contact the publisher regarding any further use of this work. Publisher contact information may be obtained at http://www.jstor.org/journals/maa.html.

Each copy of any part of a JSTOR transmission must contain the same copyright notice that appears on the screen or printed page of such transmission.

The JSTOR Archive is a trusted digital repository providing for long-term preservation and access to leading academic journals and scholarly literature from around the world. The Archive is supported by libraries, scholarly societies, publishers, and foundations. It is an initiative of JSTOR, a not-for-profit organization with a mission to help the scholarly community take advantage of advances in technology. For more information regarding JSTOR, please contact support@jstor.org. 


\title{
Hypatia and Her Mathematics
}

\author{
Michael A. B. Deakin
}

1. INTRODUCTION. The first woman mathematician of whom we have reasonably secure and detailed knowledge is Hypatia of Alexandria. Although there is a considerable amount of material available about her, very much of that is fanciful, tendentious, unreferenced or plain wrong. These limitations are to be found even in works that we might hope to be authoritative; for example, the entry in the Dictionary of Scientific Biography (DSB) [11]. Even where the account given is more careful and accurate $[14,19,20]$, one is disappointed to be told so little of Hypatia's Mathematics.

This article will direct the reader's attention to the best accessible sources and will describe what is known about her mathematical activities.

2. THE HISTORICAL BACKGROUND. In about 330 в.C., Alexander the Great conquered northern Egypt and, via a deputy (Ptolemy I Soter), founded a city (Alexandria) in the Nile delta. This almost immediately became home to the Alexandrian Museum, an institution of higher learning, rather akin to the medieval universities of some 1500 years later. Euclid was an early (probably the first) "professor" of mathematics.

The Museum continued for many centuries. In 30 B.c., Cleopatra's suicide allowed the Roman Empire to occupy Alexandria, but this event destroyed neither the city's Greek heritage nor its intellectual tradition. In the years that followed, two of the greatest of late Greek mathematicians flourished in Alexandria. Diophantus was active around A.D. 250 and produced in particular his Arithmetica at this time. Several generations later, Pappus (c.300-c.350) also worked there.

A later mathematician, Theon of Alexandria, was the last person definitely known to have been associated with the Museum. Because he recorded two eclipses (one of the sun and one of the moon) and because he is also credited with achievements during the reign of Theodosius $\mathrm{I}$, it is thought that he was at the height of his powers in the decade 360-370. Theon may well have been the last "president" of the Museum. His daughter, Hypatia, was associated with the Neo-platonic School-a different institution.

Alexandria, in the years around A.D. 400, was a turbulent mix of cultures. Christians were in the majority, but they were divided among themselves. There were also persons whom the Christians regarded as "pagans"; these could be anything from believers in the Olympian pantheon to adherents of various schools of "Neoplatonic" thought. Beyond these there were also Jews and Gnostics.

The Roman Empire, of which Alexandria was a part, was under external pressure from the Huns and the Visigoths. It split in 395 into the Western Empire (ruled from Rome) and the Eastern Empire (ruled from Constantinople). The official religion was Christianity: it had been established under Constantine. But there had been relapses; in particular, Julian the Apostate had reigned over the combined empire from 361 to 363 . 
At the time of Hypatia's death, the local governor was Orestes, a Christian not unsympathetic to other views, but whose authority was under challenge from that of the less tolerant Cyril (St. Cyril of Alexandria) who acceded to the bishopric in 412. The divisions that beset the city were prone to erupt into sectarian violence; the great libraries associated with the Museum were one by one destroyed, the last going up in smoke in 392 when the temple of Serapis was put to the torch during a riot. Another such disturbance was to claim Hypatia's life in the second decade of the fifth century. She died, brutally hacked to pieces, at the hands of a Christian lynch-mob.

Following this, very possibly in part because of it, the thrust of Neoplatonist thought and education moved from Alexandria to Athens. Three names require mention. Proclus (410?-485) was the last of the great mathematicians of Greek antiquity. He frequented the Neoplatonic School at Athens and is best remembered for a commentary on Book 1 of Euclid's Elements. After Proclus came Isidorus and his pupil Damascius (philosophers both of them rather than mathematicians, although the latter may have some claim on a place in mathematical history [6, pp. 312-313]). In 529, the emperor Justinian, enforcing Christianity as the state religion, closed the Neoplatonic School and Damascius went into exile in Persia.

3. THE PRIMARY SOURCES. The oldest accounts of Hypatia come to us from either the Suda (or Suidae) Lexicon or from the writings of the early Christian Church. For an accessible account of them, giving more detail than I provide here, see Mueller [14].

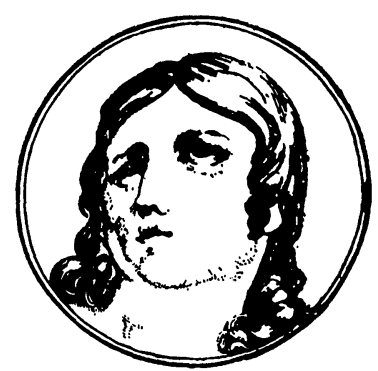

Medallion of Hypatia in the Introduction to Halma's edition of Theon's "Commentary on the Almageste". (Artist unknown)

Briefly, the Suda was a 10th-century encyclopedia, alphabetically arranged, and drawing on earlier sources. In the case of Hypatia, these are in part known. (One is a now lost work, a life of Isidorus by Damascius.) The relevant entry is unusually long, but is not seen as reliable in all its aspects (see [25]); indeed in places it contradicts itself.

"The other sources are to be found in the main in a compilation known as the Patrologiae Graecae [13], or PG for short. This gives earlier accounts (particularly of her death) than are available in the $S u d a$ and also preserves letters to her and about her from the hand of one of her pupils, Synesius of Cyrene. Also by Synesius is a letter published as a separate document included with the others in FitzGerald's translation [4].

4. LIFE AND LEGEND. The best-recorded event in Hypatia's life is her death and the manner of it. The fullest account tells us that a crowd of Christian zealots led by one Peter the Reader seized her, stripped her and proceeded to dismember 
her and burn the pieces of her corpse. Another says she was burned alive, but this would seem to be a less accurate version.

The political background to this action has been the cause of much speculation. Gibbon [5] is by no means alone in attributing the guilt for the murder to Cyril, but Rist [20] disputes this, which does mean taking issue with the Suda. Rist's account, in essence, has it that, like victims of violence in Belfast or Beirut today, she was seized not with any great selectivity at all, but rather because she was a well-known public figure, prominent on the other side of a religious divide. This to my mind is quite compatible with the statement quoted by Gibbon to the effect that she was killed because of her outstanding ability. We need not posit any specific jealousy to say this, and Rist thinks it is unlikely that precise differences of doctrine led to her death. Rist does toy with the idea that her mathematical activities were a partial cause, hypothesizing that these included astrology. This, to me, sets us on a path we have no reason to travel.

The date of her death is now generally accepted to have been 415 , although others have been suggested. See Mueller [14] for details.

The date of her birth is much less certain. (This is to be expected-people are not, generally speaking, famous when they are born.) The eclipses described by Theon, Hypatia's father, have been dated to 364 . So, from the eclipses to the time of her death is an interval of 51 years. Valesius, an early commentator on the PG who had the wrong date for the eclipses, reckoned this interval at 47 years; rounding this to 45 produces a date of c. 370 , which is the generally-stated figure. Of course, astrology aside, we have no real reason to suppose that her birth coincided with the eclipses; nor have we any idea how old Theon (or more importantly his wife) was in 364. (I tend to agree with Mueller that a date of c.350 is more plausible.)

As to her life between these uncertain dates, we may readily summarize. She was a respected and eminent teacher, charismatic even, and beloved of her pupils (e.g., Synesius). We have evidence that she was regarded as physically beautiful, that she wore distinctive academic garb, that she taught not only mathematics but

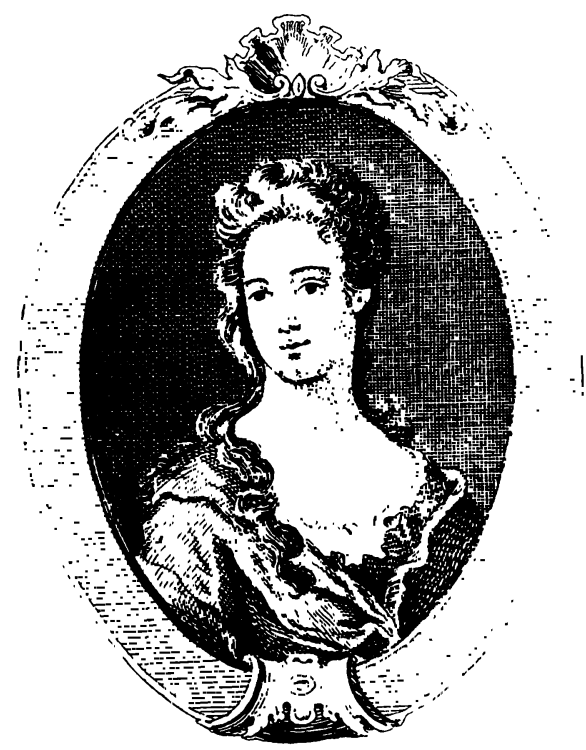


also Philosophy, that she gave public lectures and may have held some kind of public office.

She seems to have been determinedly celibate, indeed repelling one ardent suitor by confronting him with one of her used menstrual pads and lecturing him on the shameful and unclean nature of what he thought beautiful (the vagina).

Although almost all the primary sources are Christian and tell of the life and death (at Christian hands) of a prominent advocate of a rival philosophy, they do so in such a way that we are left with a favorable impression of her. My reading of this is that the official discouragement of her teachings on the part of the Church authorities and of their (Christian) civic counterparts was far from complete.

Certainly that favorable impression has informed various works of literature of which the best-known in English are Kingsley's novel [10] and the passage from Gibbon. Also fiction is Hubbard's telling of Hypatia's story [9]. It formed a chapter in a popular reader early this century and has given us the most widely disseminated "portrait" of Hypatia, attributed to an artist called Gasparo, of whom I am able to learn nothing. (Of course such "portraits" have exactly the same validity as (e.g.) Doré's illustrations of the Bible.)

5. HYPATIA'S PHILOSOPHY. The Philosophy expounded by Hypatia is known to have been Neoplatonist. There were various versions of Neoplatonism, all endowing Plato's Theory of Forms with an explicitly religious dimension. Richeson [19] describes one such system; Rist [20] suggests that Hypatia actually preached another.

Richeson does however make a particularly insightful remark on the connection between Neoplatonist Philosophy and Mathematics. The nature of Mathematics is to abstract-to derive ideas from material things. Thus Geometry, although it has its origin in the practical world of land surveyors and inspectors of weights and measures, transcends these beginnings. The Elements deals with a world that is no longer the world of the practical but rather the world of ideas. Thus Mathematics could be seen as a paradigm of that transcendence over the material that Neoplatonism enjoined.

6. HYPATIA'S MATHEMATICS. That Hypatia was a mathematician is beyond doubt. The PG tell us that she learned her Mathematics from her father Theon and went on to excel him in the subject and to teach it to numerous students. Another such source is more critical: "Isidorus greatly outshone Hypatia, not just because he was a man and she a woman, but in the way a genuine philosopher will over a mere geometer." This opinion, which will earn no praise from either women or mathematicians, is thought to derive from Damascius' life of Isidorus, the lost work that in part informed the Suda. (Marrou [12], following Tannery [25], supplies the following delightful gloss: "[it] means in plain language that Isidorus knew notking of mathematics.")

However, the Suda itself gives the most explicit account of Hypatia's mathematical works. It attributes to her the authorship of three works. The only things she is known to have written all deal with Mathematics or Astronomy. The books that many feel she must have authored on Neoplatonist Philosophy receive no mention. Others (e.g., Kramer [11]) have credited her with further works of Mathematics. For this there is no evidence, except in one specific instance to be described below. The relevant passage in the Suda is precisely twelve words long. And even this short excerpt is the subject of various alternative and disputed readings. However, there is a general consensus that Tannery [25] is correct in rendering it thus: "She 
wrote a Commentary on Diophantus, [one on] the astronomical Canon, and a Commentary on Apollonius's Conics."

"Commentaries" were what we would now refer to as "Editions" (with the obvious difference that they needed to be copied by hand), and the author of a "Commentary" is perhaps better referred to as an "Editor." Such "Editors" or "Commentators" did, however (to a greater or lesser extent, and with greater or lesser care to distinguish their own contributions from the original), provide new material of various sorts (witness Fermat's famous marginal note to Diophantus). It should be noted that in many cases the original text has come down to us only through Commentaries or translations (often into Arabic).

Theon, Hypatia's father, was a prolific author of Commentaries. He wrote one on the Elements (which, in places, still provides our present text), on two other works by Euclid, the Data and the Optics, and on two works by Ptolemy, the Almagest and the Handy Tables. There were also works now lost or partly so; particularly germane to our story is a work on the astrolabe. For this and more, see Toomer [28].

The picture that emerges of Theon is one of an editor, teacher and textbookwriter rather than a research mathematician. So is he judged, often with more than a hint of disapproval. But this should not mean that his was a wasted life. His works were preserved, presumably because they were perceived as having lasting value. It is all too understandable, given the politics of late 4th-century Alexandria and the decay of the Museum, that the emphasis on research (possible in Pappus's time) should be replaced by the priority of conserving knowledge.

After considering her works seriatim, I shall offer the hypothesis that in her scholarly priorities Hypatia was very much her father's daughter. This, as I hope I have just made clear, is not to denigrate her.

7. APOLLONIUS'S CONICS. Apollonius lived around 200 в.C. and the Conics is the most important of his surviving works. See, for more detail, Toomer's account [27]. There are very few sources for our present text and Hypatia's Commentary is not one of them. Of the eight books that make up the Conics, the first four survive via a Commentary by Eutocius while three of the remaining four have come down to us via the Arabic. The other is lost, as is also, we must conclude, Hypatia's Commentary, unless it is the lost original of Eutocius' work.

8. THE ASTRONOMICAL CANON. In the case of the "Astronomical Canon," we are much better placed. It is now generally assumed that Tannery's interpolation (the words in brackets in Section 6) in the Suda entry is correct. This means that this work also was a Commentary. The most likely original is one of the works of Ptolemy, either the Almagest or the Handy Tables. It will be remembered that Theon wrote commentaries on both these works.

Theon's commentary on the Almagest has been printed in various editions. The best and 'most recent is by A. Rome [21, 22]. (But see also [23].) It comprises separate Commentaries on the thirteen books that go to make up the Almagest. The titular inscriptions (as described by Rome from his study of the manuscripts) of the first and second books ascribe these works to Theon himself. Books 4-13 contain no inscriptions. Only the very best manuscripts contain the Commentary on Book Three, and here the inscription tells us that the work is Theon's "in the recension of my philosopher-daughter Hypatia."

Heath [8], reviewing Rome's work, thus ascribed this chapter of the Commentary to Hypatia, with the inference that it was also the work alluded to in the Suda, 
and that Theon (recognizing his daughter's work as superior to his own) had suppressed his earlier effort in favor of hers. (The pity, from our point of view, is that we don't have both versions before us; so we cannot see for ourselves where or how or to what extent Hypatia's Commentary differed from Theon's.) Rome himself discusses the matter at considerable length in his later work [22], but in such a way as not to rule out a possibility that has been canvassed: that father and daughter collaborated.

Neugebauer [16, p. 838] accepts this as likely. However, he regards it as probable that what the Suda refers to is a commentary not on the Almagest at all, but on the Handy Tables. This is because the same word (Canon) is used for both works. (Delambre [2] had earlier noted this same concordance of wording, but as his work predates Tannery's suggested interpolation, he credits Hypatia with a set of Astronomical Tables.) If the Suda were referring to a Commentary on the Almagest, so the argument goes, then it would speak of the Syntaxis, rather than the Canon. (Syntaxis is the Greek name for the work we now know by its Arabic designation.) Against this, however, is the Canon of Parsimony and the fact that Book 3 of the Almagest has a strongly tabular character.

9. DIOPHANTUS' ARITHMETIC. We may also have some of Hypatia's own writing from the Commentary on Diophantus. Diophantus' major work is the Arithmetic, originally comprising thirteen books. Of these only six now survive from the Greek, and possibly part of another, now listed as separate, the Polygonal Numbers. Tannery [26] suggested that all existing manuscripts known to him derived from a common source and that that source was Hypatia's Commentary. His careful "family tree" of the manuscripts was later modified in one detail and made available in the amended form in Heath's Edition [7]. The presumption was that Books 7-13 are lost because Hypatia's Commentary did not include them, much as Eutocius' Commentary extended only to the first four books of the Conics. This hypothesis enjoyed a deal of support, and Vogel's Article on Diophantus in the DSB simply accepts it.

The basis for this theory was the Greek text and the fact that the Suda reference to Hypatia's Commentary is the only mention of so ancient an edition. Sesiano [24, pp. 71-75] however queries this account. This is a matter of great controversy. The old theory will be presented first, but see the remarks at the end of this section.

On the old story, the mathematical world of today owes Hypatia a great debt, for without her we would have much less of the works of Diophantus. But there is an obvious corollary. If what survives for us is Hypatia's Commentary, then some of her work may appear there. It may be possible to see what is hers. One complication is that a later scribe was thought to have attempted to reconstruct Diophantus' original text and thus to have systematically omitted material he judged to be interpolated. But "the distinction between text and scholia being sometimes difficult to draw, he included a good deal which should have been left out" [7, p. 14].

On this account, the most likely of the supposed interpolations to have come from Hypatia's hand are two "student exercises" at the start of Book II. The first asks for the solution of the pair of simultaneous equations:

$$
x-y=a, \quad x^{2}-y^{2}=(x-y)+b,
$$

where $a, b$ are known. The next is a minor generalization. It requires the solution 
of the pair of simultaneous equations:

$$
x-y=a, \quad x^{2}-y^{2}=m(x-y)+b,
$$

where $a, m$ and $b$ are known. There is some evidence to link this problem to Hypatia: a nine-word phrase in the original Greek is identical with one from Euclid's Data, which her father had edited.

Recent work by Roshdi Rashed, Sesiano and others has suggested that some of the lost books of Diophantus in fact survive in Arabic translations. This has led to very great and indeed bitter controversy. What is at issue (apart from the personal rivalries involved) is whether Diophantus or someone else wrote the newly discovered works and where they might fit into the fragment previously published. Sesiano and others are inclined to the view that if anything of Hypatia's Commentary survives then it survives in the Arabic. There are no clear indications of what might be by her and what by Diophantus or by other scholiasts. Many of Sesiano's conclusions are hotly disputed by Rashed [18]. However, tentative attributions of material to Hypatia all tend to accept the overall assessment reached above-that her contributions to mathematical knowledge itself were slight or non-existent.

10. THE ASTROLABE. The other source for information about Hypatia's mathematical activities is the correspondence of Synesius.

There is a brief but telling reference to Hypatia in Synesius' essay-letter De Dono Astrolabii. The name "astrolabe" was a term applied to a variety of instruments. For a good overview of later developments, see [17]; earlier ones are discussed by Neugebauer [15]. A simple attempt to replicate the motions of the heavens in a mechanical model produces the device known as an "armillary sphere". Such an object is necessarily 3-dimensional and unwieldy, more suitable for display purposes than for use as a practical instrument of observation or computation.

However, once we have a theory of sterographic projection, the way is open for the construction of a more practical two-dimensional device. This theory was given by Ptolemy in his Planisphaerium, which even includes tabular material. Whether Ptolemy went on to develop the "little astrolabe" (i.e. the practical instrument) has been argued. Neugebauer regards it as probable that he did.

The next figure is Theon. Ptolemy died in about 170 A.D., about two centuries before Theon's active period. Theon wrote, as we have seen, Commentaries on the Almagest and the Handy Tables. The Suda also credits him with a treatise on the little astrolabe, and Arab sources refer in addition to a work of his on the armillary sphere. This set corresponds exactly to the set of works assigned to Ptolemy by the Arabs.

There is thus considerable evidence that Theon was familiar with the theory of the little astrolabe. We might speculate that he invented it, but the picture of Theon that has come down to us is one of Theon as a disseminator and conserver of knowlédge, rather than an innovator. Möreover, Neugebauer has given us grounds to believe Ptolemy to have been the inventor.

Although Theon's work on the astrolabe is now regarded as lost, Neugebauer finds such similarities between later works that they must derive from a common source. This source he believes to be Theon. He further argues (because of the exact correspondence described above) that what Theon wrote was a Commentary on an earlier book by Ptolemy.

This gives us the background to Synesius' De Dono Astrolabii. Writing to Paionos, he states that he designed the astrolabe himself with help from Hypatia 
and had it crafted by the very best of silversmiths. The inference is that the theory of the astrolabe and the details of its construction were passed down from Ptolemy, via Theon, to Hypatia, who in her turn taught Synesius.

11. THE HYDROSCOPE. Letter 15 of Synesius begins: "I am reduced to this, that I have to have a hydroscope." The letter then goes on to ask her to make him one, to quite detailed specifications. The question of what he needed is puzzling. The general presumption is that he was ill.

The term "hydroscope" usually implies a clepsydra or water-clock, but this seems inappropriate as a translation in this case. Why should he be, even if brought so low, in such urgent need of a water-clock? FitzGerald believes that Fermat (yes, the Fermat) [3] is right in suggesting that what Synesius needed was a hydrometer, that is to say, a densimeter. This makes much more sense of the specifications, which refer to the need to measure the weight of the water (the clepsydra measures the volume), and describe an instrument that sounds very like a hydrometer.

The suggestion is that Synesius needed it in his illness somehow to measure a medicine he was taking (or less plausibly the salinity of his drinking water). Hydrometers are now used, as they well may then have been, to measure the alcoholic contents of fermented or distilled liquors. Possibly Synesius was making his own medicine by some such means. My friend and colleague Charles Hunter (Department of Anatomy, Monash University) however offers a novel suggestion-that the "hydroscope" was in fact a urinometer and that the dosage of some diuretic was calculated by reference to the specific gravity of the urine.

12. ASSESSMENT. What we know of Hypatia is little enough; what we know of her Mathematics is only a small subset of that little. There is evidence that she was greatly regarded as a teacher and a scholar. The range of her acknowledged expertise was considerable. She edited works of Geometry, Algebra and Astronomy, knew how to make astrolabes and "hydroscopes", and did a lot else besides. One cannot but be impressed with this breadth of interest. Moreover, at the time of her death (assuming with Toomer [28] that Theon pre-deceased her) she was in fact the greatest mathematician then living in the Greco-Roman world, very likely the world as a whole.

She is variously described as a philosopher, a teacher of Philosophy, a mathematician and astronomer, a learned woman and a geometer.

We can understand the term "philosopher" in two senses: it has the technical sense that it retains to this day, but it also has a generic meaning of "thinker". Theon also is described in the sources as a philosopher. But this is surely in the second sense; Theon clearly emerges as a specialist mathematician and astronomer -the Suda goes on to say as much. Hypatia does not (unless one accords weight to the quote in Section 6 above); the Suda is at some pains to make this clear. "She also took up other [non-mathematical] branches of philosophy and though a woman she cast [an academic robe] around herself and appeared in the centre of the city" (Rist's translation) - the Suda then proceeds to describe the Philosophy she taught, mentioning the work of Plato and Aristotle, in particular.

However, if we restrict consideration to Mathematics alone, we may well query the usual judgment that Hypatia outclassed her father. It comes from the PG and modern sources regularly repeat it uncritically. We may also deduce it from Theon's heading to his Commentary of Book 3 of the Almagest. 
We may still however dispute this opinion and indeed argue the opposite. That a fond father might recognise and promote his daughter's improvement of one of his own works is understandable enough. That ecclesiastical historians, of whom we have no evidence of mathematical ability, might use fame or even notoriety as an index of talent is equally so. But this does not end the matter.

While it is of course too much to posit a universal theory of natural selection of scholarly works (it being by no means always true that the best works are the survivors) nonetheless scholars of earlier times preserved, translated and taught from those works they adjudged as valuable. Much as we do today. In fact, we do know something of the principle of natural selection that operated. Because the focus had moved from research to conservation, those works were preserved that were well regarded as textbooks [29]. Many research works from the period are lost.

We have no evidence of research Mathematics on the part of either father or daughter. What we can reconstruct of their Mathematics suggests to us that they edited, preserved, taught from and supplied minor addenda to the works of others. A great deal of Theon's work survives and at most a small part of Hypatia's. In other words Theon was seen as the better text-writer, even if he himself generously demurred in one case.

Where Hypatia does quite clearly outshine Theon is in her reputation as a teacher. She was revered as such and no similar endorsement of Theon has come down to us. (It is perfectly possible that this is the basis of the orginial statement.) We are left with a well-attested account of a popular, charismatic and versatile teacher. And that, I suggest, is the best picture we can form of her.

ACKNOWLEDGMENT. The present article is an abridgement of a longer original [1]. I am grateful to G. J. Tee of the University of Auckland for his careful criticism of the earlier draft and for bringing reference [14] to my attention.

\section{REFERENCES}

1. Deakin, M. A. B., "Hypatia the Mathematician", Monash University History of Mathematics Pamphlet 52 (1991).

2. Delambre, J. B. J., Histoire de l'Astronomie Ancienne 2 (New York: Johnson, 1965; reprint of an 1817 original), 317.

3. Fermat, P.,Euvres 1 (Ed. P. Tannery and C. Henry) (Paris: Gauthier, 1891), 352-365.

4. FitzGerald, A. (ed. and trans.), The Letters of Synesius of Cyrene (London: Oxford University Press, 1926).

5. Gibbon, E., The Decline and Fall of the Roman Empire (first published 1776-1788; many subsequent editions), Chapter 47.

6. Gow, J., A Short History of Greek Mathematics (New York: Chelsea, 1968; reprint of an 1884 original), 312-313.

7. Heath, T. L., Diophantus of Alexandria (Cambridge University Press, 1885; Dover reprint, 1964).

8. Heath T. L., Review of Ref. [21], Class. Rev. 52 (1938), 40.

9. Hubbafd, E., Little Journeys [to the Homes of Great Teachers] 23 (4) (East Aurora, NY: Roycrofters, 1908).

10. Kingsley, C., Hypatia (first published 1851; many subsequent editions).

11. Kramer, E. E., Article on Hypatia, DSB 6, 615-616.

12. Marrou, H. I., "Synesius of Cyrene and Alexandrian Neoplatonism", in The Conflict between Paganism and Christianity in the Fourth Century (Ed. A. Momigliano) (Oxford: Clarendon, 1963), 126-150.

13. Migne, J.-P. (ed.) Patrologiae Graecae (Paris: Migne, 1857-1866).

14. Mueller, I., "Hypatia", in Women of Mathematics: A Biobibliographic Sourcebook (Ed. L. S. Grinstein and P. J. Campbell) (New York: Greenwood, 1987).

15. Neugebauer, O., "The Early History of the Astrolabe", Isis 40 (1949), 240-256. 
16. Neugebauer, O., A History of Ancient Mathematical Astronomy (Berlin: Springer, 1975).

17. North, J. D., “The Astrolabe”, Sci. Am. 230 (1), (Jan. 1974), 96-106.

18. Rashed, R., Review of Ref. [24], Math. Rev. 85h:01006.

19. Richeson, A. W., "Hypatia of Alexandria", Nat. Math. Mag. 15 (1940), 74-82.

20. Rist, J. M., "Hypatia", Phoenix 19 (1965), 214-225.

21. Rome, A., Commentaires de Pappus et de Théon d'Alexandrie sur l'Almageste (2), Studi e Testi (Vatican) 72 (1936).

22. Rome, A., Commentaires de Pappus et de Théon d'Alexandrie sur l'Almageste (3), Studi e Testi (Vatican) 106 (1943).

23. Rome, A., "Le troisième livre des commentaires sur l" Almageste" par Théon et Hypatie", (Paris: Presses universitaires de France, 1926; excerpted from Ann. Soc. Sci. Bruxelles 46, 1926)

24. Sesiano, J., Books IV to VII of Diophantus'Arithmetica (New York: Springer, 1982).

25. Tannery, P., "L'article de Suidas sur Hypatia", Ann. Fac. Lettres Bordeaux 2 (1880), 197-200.

26. Tannery, P., Diophanti Alexandrini opera omnia (Leipzig: Teubner, 1893-1895).

27. Toomer, G. J., Article on Apollonius, DSB 1, 179-193.

28. Toomer, G. J., Article on Theon, DSB 13, 321-325.

29. Toomer, G. J., "Lost Greek Mathematical Works in Arabic Translation", Math. Intell. 6 (2) (1984), 32-38.

Addendum: Too late for mention in the main article, I was made aware of the lengthy discussion of Hypatia by W. R. Knorr [Textual Studies in Ancient and Medieval Geometry (Boston: Birkhauser, 1989)]. Beginning from a stylistic analysis of Book Three of Theon's Commentary on the Almagest, Knorr builds an elaborate and detailed, though speculative, argument to attribute several other lost works to Hypatia. In particular, he suggests that Eutocius' Commentary on Apollonius' Conics in fact derives from Hypatia's earlier Commentary, the one mentioned in the Suda.

I thank Win Frost of the University of Newcastle (Australia) for bringing Knorr's work to my attention.

Department of Mathematics

Monash University

Clayton, Vic. 3168

Australia

"The main duty of the historian of mathematics, as well as his fondest privilege, is to explain the humanity of mathematics, to illustrate its greatness, beauty and dignity, and to describe how the incessant efforts and accumulated genius of many generations have built up that magnificent monument, the object of our most legitimate pride as men, and of our wonder, humility and thankfulness, as individuals. The study of the history of mathematics will not make better mathematicians but gentler ones, it will enrich their minds, mellow their hearts, and bring out their finer qualities."

-G. Sarton 